\title{
Multiple Sclerosis and Pregnancy; Disease Activity and Disease Progression in Pregnancy and Postpartum Period
}

\author{
Multipl Skleroz ve Gebelik; Gebelik ve Postpartum Dönemde Hastalık Aktivitesi \\ ve Hastalık Progresyonu
}

Vedat Çilingir

Van Yuzuncu Yil University, Faculty of Medicine, Neurology Department, Van, Turkey

\begin{abstract}
Objective: In this study, it was aimed to investigate how pregnancy and postpartum processes affect the course of MS disease, the effects of breast feeding on the frequency of attacks, and the fetal development in pregnant patients using MS treatment (disease modifying treatment (DMT)).

Materials and Methods: Our pregnant relapsing remitting MS (RRMS) patients who were followed up in our MS outpatient clinic were included in the study. Our patients were followed up during pregnancy and postpartum 1 year. Disability status was evaluated using the Expanded Disability Status Scale (EDSS). Annualized relapse rate (ARR) was calculated in the year preceding pregnancy, during pregnancy, and in the first year of postpartum. The duration of DMT use while pregnant, pregnancies resulting in miscarriage, low birth weight babies, preterm babies, and breastfeeding times were recorded and evaluated.

Results: The number of pregnancies followed was 102 pregnancies, including 89 deliveries and 13 abortions. Twenty nine patients used DMT in some part of their pregnancy due to unplanned pregnancy. The disability condition evaluated before and 12 months after pregnancy progressed in 12 patients. Interestingly, 70 patients remained stable, while seven patients regressed. No relation was found between the use of DMT during pregnancy and miscarriage, preterm baby, and low birth weight baby. Mothers who were not breastfeeding or breastfeeding for less than 3 months experienced more attacks than mothers who breastfed for 3 months or more.

Conclusion: Disease activity and disability status during pregnancy and the postpartum period did not change in RRMS patients compared to pre-pregnancy. DMTs used during pregnancy did not affect fetal development and abortion status.

Key Words: Pregnancy, Multiple Sclerosis, Breast Feeding, Annualized Relapse Rate, Disease Progression, Postpartum Period
\end{abstract}

\section{Objective}

Multiple Sclerosis (MS) is an autoimmune, chronic inflammatory disease that is about 3 times more common in women than men. Most of the patients are in the Relapsing Remitting Multiple Sclerosis (RRMS) subtype whereby new

\section{Özet}

Amaç: Amacımız gebelik ve postpartum sürecin MS hastalığının seyrini nasıl etkilediğini araştırmak, emzirmenin atak sıklığ 1 üzerine etkilerini araştırmak, gebe iken MS tedavisi (DMT) kullanan hastalarda bebek gelişimini araştırmaktır.

Gereç ve Yöntem: MS polikliniğimizde takip ettiğimiz gebe olan Relapsing Remitting MS (RRMS) hastalarımız çalışmaya dahil edildi. Hastalarımız gebelik ve postpartum 1 vil boyunca takip edildi. Özürlülük durumu Expanded Disability Status Scale (EDSS) ile değerlendirildi. Gebelikten önceki yılda, gebelik boyunca ve postpartum birinci yılda y1llık atak oranları (ARR) hesaplandı. Hastalarımızın gebe iken DMT kullanma süreleri, düsük ile sonuclanan gebelikler, düsük doğum ağırlıklı bebekler, preterm bebekler, emzirme süreleri kaydedildi.

Bulgular: 89 doğum ve 13 abortus ile sonuçlanan 102 gebelik takip edildi. 29 hasta plansız gebelik nedeni ile gebeliğinin bir kısmında DMT kullandı. Gebelik döneminde 20 atak, postpartum 12 ayda 30 atak yaşand. Hastaların gebelik öncesi 1 yılda, gebelik süresince ve postpartum 12 ayda ARR değerlerinde anlamlı farklılık oluşmadı. Gebelik öncesi ve gebelik sonrası 12 ayda değerlendirilen özürlülük durumu 12 hastada ilerledi 70 hasta stabil kald1 ve 7 hastada geriledi. Gebelikte DMT kullanımı ile düşük, preterm bebek, düşük doğum ağıllıklı bebek arasında ilișki saptanmadı. Emzirmeyen veya 3 aydan az emziren anneler 3 ay veya daha fazla emziren annelerden daha fazla atak yaşadı.

Sonuç: RRMS hastalarında gebelikte ve postpartum dönemde hastalık aktivitesi ve özürlülük durumunu gebelik öncesine göre değişmedi. Gebe iken kullanılan DMT ler bebek gelișimini ve düsük durumunu etkilemedi. 3 ay veya daha uzun süre emzirme atak sıklığını düşürdü.

Anahtar Kelimeler: Multipl Skleroz, Gebelik, Hastalık Progresyonu, Y1llık Atak Hızı, Emzirme, Postpartum Dönem

neurological symptoms occur or worsening of existing findings occur as a consequence of recurrent inflammatory attacks. The remaining patients constitute the Progressive Multiple Sclerosis subtype in which the disability progresses independently of the attacks. MS 
disease causes atrophy in the central nervous system (1) and the aggressive MS disease may cause disability within a few years. MS patients are most commonly diagnosed between the ages of 20-40, which is also the prime age range for fertility in women. Disease modifying treatments (DMT) for MS are not recommended for use in pregnant women. Although the use of drugs in pregnancy is not recommended, many pregnancies occur each year when DMT is used. The effects of DMT use on the pregnancy process and fetal development bear many questions (2). The annual relapse rate (ARR) of RRMS patients not receiving treatment is around 1.0 (3). DMT discontinuation is recommended for MS patients before conception. Pregnancy and the postpartum period can be a challenging process for the mother and doctor. As important changes in maternal physiology occur, the fetus that is vulnerable to external factors and MS disease in which treatment can be interrupted. While some studies reported that the rate of attacks decreased during pregnancy and increased in the postpartum period in patients with RRMS (4, 5), studies defending the opposite have been published recently $(6,7)$. The relationship between breastfeeding and disease activity in MS patients is also a subject of study and discussion $(8,9)$. The aims of this study are to: 1 - investigate the effect of pregnancy and postpartum period on the course of the disease and the frequency of attacks in MS patients; 2- to investigate the effects of breastfeeding and duration of breastfeeding on the frequency of attacks; and 3- to investigate the development of fetus and possible congenital malformations in patients who conceive while using DMT.

\section{Materials and Methods}

We evaluated pregnant women who were diagnosed with as RRMS according to 2005 McDonald or 2010 McDonald diagnostic criteria in our MS outpatient clinic. We compared the follow-up data of the patients one year before, during, and one year after pregnancy. In our MS outpatient clinic, our patient data were recorded using the iMed (C) program (iMed; Geneva). Our study was approved by the ethics committee of Van Yüzüncü Yıl University (Official Decision number: 2021/04-04). Criteria for inclusion in the study were as follows: 1-attending regular outpatient clinic follow-ups in our clinic; 2-being in the having RRMS disease course; 3- being the patient's pre-pregnancy data are complete; and 4agreeing to participate in the study by signing the informed consent form. Patients with a history of recurrent abortion and those with diseases other than MS that could affect the pregnancy process were excluded from the study. Abortions performed without medical justification were excluded from the study. Patients were evaluated at our MS outpatient clinic at 3-4 month intervals, and neurological examination and history of attack were recorded. Disability status of the patients was evaluated using the Expanded Disability Status Scale (EDSS). If at least a single unit increase in EDSS score was also present at the examination 3-4 months later, it was defined as a disability progression. EDSS score was calculated at least 30 days after the nearest attack. The last EDSS score measured before pregnancy was defined as the first EDSS score and the measurement following postpartum 12 months was defined as the final EDSS score. Attack was defined as the presence of a demyelinating neurological symptom lasting more than 24 hours in the absence of fever and infection. Our patients were followed up for 12 months postpartum. The number of attacks experienced by MS patients in 1 year was defined as the Annualized relapse rate (ARR). The ARR values of our patients in one year before pregnancy, during pregnancy, and in the first year of postpartum were calculated and compared. Regardless of the number or amount of breastfeeding per day, mothers who were breastfeeding regularly every day were accepted as breastfeeding mothers as long as they were still breastfeeding. The first attack date of the patients was defined as the date of onset of the disease and the time until conception as the duration of the illness. The ages of the patients at the beginning of pregnancy were used in the analyses. DMT, which the patients used regularly in the first year before pregnancy, was accepted as pre-pregnancy treatment. DMT was discontinued before conception according to the properties of the drug used in planned pregnancies. Most of the patients with unplanned pregnancy stopped the treatment when they realized that they were pregnant, and some preferred to continue the treatment and discontinue it after the polyclinic control. If the birth date of the baby was below 37 weeks, then it was considered to be a preterm baby; if the baby's weight was below $2,500 \mathrm{mg}$, 


\section{4 pregnancies were excluded from the} study;

7 patients had deficiencies in pre-pregnancy data

2 patients had a history of recurrent abortion

4 patients refused to participate in the study

1 patient had Behçet's disease.

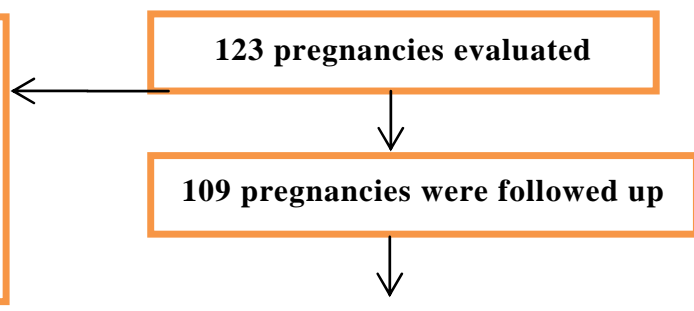

7 pregnancies were excluded from follow-

up;

3 patients disrupted their polyclinic follow-up

4 patients terminated their pregnancy

102 pregnancies completed the study

Figure 1. Flowchart.

Table 1: Clinical characteristics of all pregnancies.

\begin{tabular}{|c|c|c|c|c|}
\hline Characteristic & All pregnancies & $\begin{array}{c}\text { Pregnancies resulting in } \\
\text { birth }\end{array}$ & $\begin{array}{c}\text { Pregnancies that do not result } \\
\text { in birth }\end{array}$ & $\mathrm{p}$ \\
\hline Number (\%) & 102 & $89(87.2)$ & $13(12.7)$ & \\
\hline Age (years) & $29.41 \pm 5.51$ & $29.23 \pm 5.50$ & $30.61 \pm 5.59$ & $0.418^{1}$ \\
\hline \multicolumn{5}{|l|}{ Duration of disease (months) } \\
\hline $\begin{array}{l}\text { Pre-pregnancy median EDSS } \\
\text { score (IQR) }\end{array}$ & $1(2.0)$ & $1(2.0)$ & $1(1.75)$ & $0.45^{2}$ \\
\hline $\begin{array}{l}\text { Median EDSS score (IQR) in } \\
\text { postpartum } 12 \text { months }\end{array}$ & - & $1(2.0)$ & - & $0.19^{3}$ \\
\hline $\begin{array}{l}\text { Number of patients using } \\
\text { DMT before pregnancy (\%) }\end{array}$ & $77(75.4)$ & $69(77.5)$ & $8(61.5)$ & $0.62^{4}$ \\
\hline \multicolumn{5}{|l|}{$\begin{array}{l}\text { DMT used before pregnancy n } \\
(\%)\end{array}$} \\
\hline Interferon beta & $36(46.7)$ & 32 & 4 & \\
\hline Glatiramer acetate & $24(31.1)$ & 22 & 2 & \\
\hline Fingolimod & $10(12.9)$ & 10 & 2 & \\
\hline Dimethyl fumarate & $5(6.5)$ & 5 & 0 & \\
\hline $\begin{array}{l}\text { Number of patients using } \\
\text { DMT while pregnant }\end{array}$ & 40 & 35 & 5 & $0.95^{4}$ \\
\hline
\end{tabular}

$1=$ Independent samples t-test $\mathrm{p}$ value that compares the age and disease duration of pregnancies that resulted in birth and did not result in birth.

2 = P value of the Mann-Whitney test that compares the initial EDSS values of pregnancies that resulted in birth and did not result in birth.

$3=\mathrm{P}$ value of Wilcoxon Signed Ranks test comparing the first and last measured EDSS values of pregnancies resulted in birth.

$4=$ Chi Square test $\mathrm{p}$ value that compares pregnancies that resulted in birth and did not result in birth in terms of DMT use.

$\mathrm{IQR}=$ Interquartile Range, DMT = Disease Modifying Treatment, EDSS = Expanded Disability Status Scale.

then it was considered to be a low birth weight baby. Since the data of each birth differed, the second birth of the same patient was recorded as different data. In the postpartum period, 2 patients had 2 attacks each; therefore, the data of each attack were evaluated separately.

Statistical Analysis: All statistical analyzes were done using the SPSS statistics 21.0 (IBM SPSS; 
Armonk, NY) program. The compliance of the data to normal distribution was analyzed using the Shapiro-Wilk test. Numerical values were defined by mean and standard deviation. Parametric tests were used while evaluating normally distributed data. Nonparametric tests were used to evaluate the EDSS score, which is ordinal data. Comparisons of age and duration of illness between groups were made using the Independent samples analysis of variance (ANOVA) test. In our study population, ARR was calculated at 3 different time intervals for each pregnancy and the values were analyzed using the Repeated-measures ANOVA test. EDSS scores were calculated at two different times, and the Wilcoxon signed ranks test was used to compare the values. MannWhitney test was used to investigate the distribution of EDSS scores in patient subgroups. The presence of postpartum attack among patient subgroups was analyzed using Fisher's exact test. The distribution of categorical variables between patient groups was compared using the Chi square test. A p-value of less than 0.05 was considered statistically significant.

\section{Results}

One hundred two pregnancies of 93 RRMS patients were included in the study. The average age of the patients was $29.5 \pm 5.5$ years and the average disease duration was $60.4 \pm 39.5$ months. There were 77 patients using DMT regularly before pregnancy. While 89 of 102 pregnancies resulted in deliveries, 10 pregnancies ended with miscarriage and 3 pregnancies terminated with therapeutic abortion. There was no difference between pregnancies that resulted in delivery and those that did not in terms of DMT use during pregnancy (chi square test $\mathrm{p}=0.95$; Table 1). DMT was discontinued before conception in 34 pregnancies that resulted in delivery and DMT was used for a while in 35 pregnancies. Six of these patients continued DMT by their own decision during their entire pregnancy and postpartum period (three patients were using Glatiramer acetate and the other three were interferon beta). DMTs used during pregnancy are listed in Table 1. Seventeen patients stopped DMT in the first month of their pregnancy, 7 patients used DMT for 1-3 months, 4 patients stopped after using DMT for more than 3 months, and 6 patients used it continuously. EDSS score measured at the end of postpartum 1 year in 12 patients increased compared to pre-pregnancy, 70 patients did not change, and EDSS score decreased in 7 patients compared to prepregnancy. There was no difference between the first and last measured EDSS values in the study population (Wilcoxon signed ranks test $\mathrm{p}=0.19$ ). Of the 89 deliveries followed, 17 had a low birth weight baby and 13 a preterm baby. Congenital malformation was not detected in any baby. When pregnancies resulted in low birth weight and preterm babies were compared with pregnancies resulting in normal, no difference was observed in terms of maternal age, disability status of the mother before pregnancy, duration of illness, use of DMT during pregnancy and attacks during pregnancy (Table 2). Twenty patients had an attack during pregnancy. There was no difference in the distribution of attacks according to trimesters between pregnancies that resulted in normal and pregnancies that resulted in low birth weight babies and preterm babies (Fisher's exact test $p=0.22$ ). During pregnancy, most of the attacks occurred at 1 and 2 trimesters, and only $10 \%$ of the attacks occurred in the third trimester (chi square test $\mathrm{p}<0.01$ ). During the follow-up period, 30 attacks occurred in the postpartum period. While analyzing the patients who had attacks, 2 patients had 2 attacks each and the data of each attack were recorded separately. Twenty one patients did not breastfeed at all or breastfed for less than 3 months, and 70 patients' breastfed for 3 months or more. It was observed that mothers who did not breastfeed in the postpartum period or who breastfed for less than 3 months had more attacks (chi square test continuity correction $\mathrm{p}=0.03$ ). In addition, no relationship was found between breastfeeding and disability progression $(p=0.09)$ (Table 3$)$. ARR values of the followed-up patients were calculated in one year before pregnancy, during pregnancy and in the first year of postpartum. In our study population, pre-pregnancy ARR $=0.33$, during pregnancy $A R R=0.29$ and postpartum period ARR $=0.33$. Repeated-measures ANOVA test was used to compare ARR values. It was observed that there was no difference between the values (Greenhouse-Geisser p $=0.81$ ). 
Table 2: Comparison of pregnancies resulting in preterm babies or low birth weight babies and normal full term pregnancies.

\begin{tabular}{lccc}
\hline Characteristic & $\begin{array}{c}\text { Pregnancies resulting in } \\
\text { normal }\end{array}$ & $\begin{array}{c}\text { Pregnancies resulting in preterm } \\
\text { babies or low birth weight babies }\end{array}$ & p \\
\hline Number (\%) & $70(78.6)$ & $19(21.3)$ & $0.50^{1}$ \\
Age (years) & $29.44 \pm 5.66$ & $28.47 \pm 4.97$ & $0.67^{1}$ \\
Duration of disease (months) & $60.94 \pm 37.77$ & $56.63 \pm 45.49$ & $0.46^{2}$ \\
Pre-pregnancy median EDSS score & $1.0(2.0)$ & $1.0(1.5)$ & $0.28^{3}$ \\
(IQR) & $1.0(2.0)$ & $1.0(2.0)$ & $0.22^{4}$ \\
Median EDSS score after pregnancy & $25(71.4)$ & $10(28.5)$ & $0.00^{5}$ \\
Number of patients using DMT & & 2 & \\
while pregnant (\%) & 18 & & \\
Number of patients with an attack & & 0 & 0 \\
during pregnancy & 8 & & \\
Distribution of attacks by trimesters & 8 & & \\
1st trimester & 2 & & \\
2nd trimester & & & \\
3rd trimester & & & \\
\hline
\end{tabular}

$1=$ Independent samples t-test $\mathrm{p}$ value that compares the age and disease duration of pregnancies resulted in normal and pregnancies with preterm or low birth weight.

$2=\mathrm{P}$ value of the Mann-Whitney test that compares the initial EDSS values of pregnancies resulted in normal and pregnancies that result in preterm or low birth weight babies.

$3=$ Chi Square test Continuity correction p value that compares of DMT use of pregnancies resulted in normal and pregnancies resulted in preterm or low birth weight babies

$4=$ Fisher's exact test $\mathrm{p}$ value that compares the number of attacks during pregnancy of pregnancies resulted in normal and pregnancies resulted in preterm or low birth weight babies

$5=$ Chi Square test $\mathrm{p}$ value evaluating the distribution of attacks according to trimesters in pregnancies that result in delivery.

IQR = Interquartile Range, DMT $=$ Disease Modifying Treatment, EDSS $=$ Expanded Disability Status Scale.

Table 3: Comparison of the study population by breastfeeding status.

\begin{tabular}{lccc}
\hline Characteristic & All population & $\begin{array}{c}\text { Mothers who are not } \\
\text { breastfeeding or } \\
\text { breastfeeding for less } \\
\text { than } 3 \text { months }\end{array}$ & $\begin{array}{c}\text { Breastfeeding mothers } \\
\text { for } 3 \text { months or more }\end{array}$ \\
$\begin{array}{l}\text { Number (\%) } \\
\begin{array}{l}\text { Number of patients had } \\
\text { postpartum attacks }\end{array}\end{array}$ & $91^{1}$ & $21(23)$ & $70(76.9)$ \\
$\begin{array}{l}\text { The month of Postpartum } \\
\text { attack }\end{array}$ & 30 & 11 & 19 \\
$\begin{array}{l}0-6 \\
7-12\end{array}$ & 19 & 7 & 12 \\
\hline
\end{tabular}

$1=$ since 2 patients had 2 attacks each in the postpartum period, the population was analyzed as 91 people.

$2=$ Chi square test continuity correction $\mathrm{p}$ value, which analyzes the presence of attacks among groups formed according to breastfeeding status.

\section{Discussion}

Important findings of our study were: 1- ARR values of our patients did not change in 1 year before pregnancy, during pregnancy, or in the first year of postpartum; 2- the disability status of our patients did not change at the end of the postpartum first year compared to pre-pregnancy; 3 - in the postpartum period, mothers who did not breastfeed or breastfed for less than 3 months had more attacks compared to mothers who breastfed for 3 months or more; and 4- Use of DMT during pregnancy was not associated with miscarriage, preterm baby or low birth weight baby. In our study, it was observed that the attack rates during pregnancy decreased slightly, and reached its prepregnancy state in the postpartum period (it did not reach a statistically significant level). In the pregnancies we followed up, most of the attacks occurred in the first two trimesters, while only 
$10 \%$ of the attacks occurred in the third trimester. Our findings are consistent with previous studies $(4,5,10-12)$. Finkelsztejn et al. (12), in a metaanalysis in which they evaluated a total of 1,221 pregnancies in 13 studies, reported that the attack rates of MS patients decreased during pregnancy and increased again in the postpartum period. The results of a study that followed 335 MS patients using interferon-beta or glatiramer acetate (4) and another study that followed 893 MS patients (5) are consistent our results. The reason for the decreased attack rates during pregnancy is unknown. The strongest hypothesis is that the increased estrogen and progesterone hormones during pregnancy shift the immune system activity towards an anti-inflammatory Th2 response (13). In our study, we concluded that pregnancy did not affect the disability status of our patients. While some studies supported our findings $(14,15)$, there are studies that have reached different results. Jokubaitis et al., in a study in which they followed 1,830 MS patients for 10 years, showed that patients who gave birth after MS diagnosis had lower disability scores than patients who did not give birth (16). However, no significant relationship was found in studies investigating the relationship between the number of pregnancies and disease progression $(17,18)$. In most of the studies, it has been concluded that pregnancy had no effect on MS progression (19). Mothers with MS who have just given birth have to choose between not breastfeeding and starting DMT or breastfeeding their babies but facing the risk of an attack. In our study, we observed that mothers who breastfed for 3 months or more had less attacks in the postpartum period. Hellwig et al. (8) investigated the relationship between breastfeeding and the frequency of attacks in 201 MS patients. They concluded that intensive breastfeeding reduced the frequency of attacks only in the first 6 months after birth. In their meta-analysis, Pakpoor et al. (9) evaluated 12 studies and concluded that breastfeeding has a decreasing effect on disease activity in MS. In our study, most of our patients used DMT while they were pregnant, and we found that there was no relationship between DMT use and fetal development problems. Most of the drugs used are glatiramer acetate and interferon beta. In previous studies evaluating MS patients using these two drugs while pregnant, they reached conclusions in line with our findings $(20,21)$. In our study, since the number of patients using other DMTs while pregnant is low, we prefer not to comment on these drugs. Two issues should be kept in mind when evaluating studies analyzing the pregnancies of MS patients. The first is the fact that patients with an active course of MS tend to avoid pregnancy, and patients with a stable course of MS get pregnant. Therefore, studies were conducted with patients with relatively lower MS activity. The second is the fact that environmental factors such as cigarette and alcohol consumption, vitamin deficiency, and socio-economic status can affect study results. We should mention some limitations regarding our study. Although the number of pregnancies we follow is a successful number for a single MS center, multi-center studies with broad participation are needed on this subject. The second point is that radiological activity is as important as clinical activity in MS disease. In our study, it was not possible to evaluate radiological activity because the pre-pregnancy imaging times of our patients varied.

\section{Conclusion}

In our study, it was observed that pregnancy does not have a negative effect on MS activity and the patient's disability. The frequency of attacks decreased slightly during pregnancy and returned to normal before pregnancy in the postpartum period. In our study, congenital malformation, low birth weight and preterm delivery rates did not increase as a result of DMT used during pregnancy. Breastfeeding for 3 months or more reduced the frequency of attacks in the postpartum period.

Acknowledgements: The authors thank all the people who took part in this study.

Funding: This research did not receive any specific grant from funding agencies.

\section{References}

1. Cilingir V, Akdeniz $H$. The course of cervical spinal cord atrophy rate and its relationship with NEDA in relapsing remitting multiple sclerosis. Acta Neurol Belg 2021.

2. Langer-Gould AM. Pregnancy and Family Planning in Multiple Sclerosis. Continuum (Minneap Minn) 2019; 25(3): 773-792.

3. Inusah S, Sormani MP, Cofield SS, Aban IB, Musani K,Srinivasasainagendra V, et al. Assessing changes in relapse rates in multiple sclerosis. Multiple sclerosis (Houndmills, Basingstoke, England). 2010; 16(12): 1414-1421. 
4. Hellwig K, Haghikia A, Rockhoff M, Gold R. Multiple sclerosis and pregnancy: experience from a nationwide database in Germany. Ther Adv Neurol Disord 2012; 5(5): 247-253.

5. Hughes SE, Spelman T, Gray OM, Boz C, Trojano M, Lugaresi A, et al. Predictors and dynamics of postpartum relapses in women with multiple sclerosis. Multiple sclerosis (Houndmills, Basingstoke, England). 2014; 20(6): 739-746.

6. Alroughani R, Alowayesh MS, Ahmed SF, Behbehani R, Al-Hashel J. Relapse occurrence in women with multiple sclerosis during pregnancy in the new treatment era. Neurology 2018;90(10): e840-e846.

7. De Giglio L, Gasperini C, Tortorella C, Trojano M, Pozzilli C. Natalizumab discontinuation and disease restart in pregnancy: a case series. Acta Neurol Scand 2015; 131(5): 336-340.

8. Hellwig K, Rockhoff M, Herbstritt S, Borisoe N, Haghikia A, Elias-Hamp B et al. Exclusive Breastfeeding and the Effect on Postpartum Multiple Sclerosis Relapses. JAMA Neurol 2015;72(10): 1132-1138.

9. Pakpoor J, Disanto G, Lacey MV, Hellwig K, Giovannoni G, Ramagopalan SV. Breastfeeding and multiple sclerosis relapses: a meta-analysis. J Neurol 2012;259(10): 2246-2248.

10. Confavreux C, Hutchinson M, Hours MM, Cortinovis-Tourniaire P, Moreau T. Rate of pregnancy-related relapse in multiple sclerosis. Pregnancy in Multiple Sclerosis Group. N Engl J Med 1998; 339(5): 285291.

11. Vukusic S, Hutchinson M, Hours M, Moreau T, Cortinovis-Tourniaire P, Adeleine $\mathrm{P}$ et al. Pregnancy and multiple sclerosis (the PRIMS study): clinical predictors of post-partum relapse. Brain 2004;127(Pt6): 1353-1360.

12. Finkelsztejn A, Brooks JB, Paschoal FM, Jr., Fragoso YD. What can we really tell women with multiple sclerosis regarding pregnancy? A systematic review and meta- analysis of the literature. Bjog 2011; 118(7): 790-797.

13. Gold SM, Voskuhl RR. Pregnancy and multiple sclerosis: from molecular mechanisms to clinical application. Semin Immunopathol 2016; 38(6): 709-718.

14. Ramagopalan S, Yee I, Byrnes J, Guimond C, Ebers G, Sadovnick D. Term pregnancies and the clinical characteristics of multiple sclerosis: a population based study. J Neurol Neurosurg Psychiatry 2012; 83(8): 793-795.

15. Karp I, Manganas A, Sylvestre MP, Ho A, Roger E, Duquette P. Does pregnancy alter the long-term course of multiple sclerosis? Ann Epidemiol. 2014;24(7): 504508.e502.

16. Jokubaitis VG, Spelman T, Kalincik T, Lorscheider J, Havrdova D, Duquette P, et al. Predictors of long-term disability accrual in relapse-onset multiple sclerosis. Annals of neurology 2016; 80(1): 89-100.

17. D'Amico E, Leone C, Patti F. Offspring Number Does Not Influence Reaching the Disability's Milestones in Multiple Sclerosis: A Seven-Year Follow-Up Study. Int J Mol Sci 2016; $17(2): 234$.

18. Altintas A, Najar B, Gozubatik-Celik G, Menku SF. Pregnancy Data in a Turkish Multiple Sclerosis Population. Eur Neurol 2015;74(5-6): 296-302.

19. Nguyen AL, Eastaugh A, van der Walt A, Jokubaitis VG. Pregnancy and multiple sclerosis: Clinical effects across the lifespan. Autoimmun Rev 2019;18(10): 102360.

20. Thiel S, Langer-Gould A, Rockhoff M, Haghikia A, Queisser-Wahrendorf A, Gold $\mathrm{R}$ et al. Interferon-beta exposure during first trimester is safe in women with multiple sclerosis-A prospective cohort study from the German Multiple Sclerosis and Pregnancy Registry. Multiple sclerosis (Houndmills, Basingstoke, England) 2016; 22(6): 801-809.

21. Voskuhl R, Momtazee C. Pregnancy: Effect on Multiple Sclerosis, Treatment Considerations, and Breastfeeding. Neurotherapeutics 2017; 14(14): 974-984. 